\title{
HABITAT PERKOTAAN DI KOTA KUPANG
}

\author{
Yoseph Liem ${ }^{1}$, Rilia Rigina Mahagarmitha ${ }^{2}$ \\ 1,2. Program Studi Magister Arsitektur, Fakultas Arsitektur dan Desain, \\ Universitas Kristen Duta Wacana \\ Jl. dr. Wahidin Sudirohusodo No. 5-25 Yogyakarta \\ Email: 11iem_architects@yahoo.com, ${ }^{2}$ mahagarmitha.08@gmail.com
}

\begin{abstract}
Abstrak
Isu perebutan ruang kota di Indonesia tidak hanya pada pemanfaatan ruang saja, tetapi juga pada hilangnya habitat pembentuk kota atau ruang kota, khususnya di Kota Kupang yang merupakan ibukota Provinsi Nusa Tenggara Timur, sekaligus daerah perbatasan dengan negara Timor Leste. Kota Kupang yang berkembang saat ini terus melakukan pembangunan hingga ke kawasan pesisir pantai dan sangat bertentangan dengan peraturan yang sudah dibuat sebelumnya. Kawasan yang menjadi studi kasus dalam penelitian ini ialah pantai Pasir Panjang - Kelapa Lima, dimana lokasi ini sebelumnya merupakan habitat koloni nelayan di wilayah pesisir dalam Kota Kupang. Selain itu, lokasi ini merupakan ruang publik. Penelitian ini bertujuan untuk mengetahui penggunaan dan konflik ruang di Kota Kupang dengan menggunakan metode penelitian deskriptif, melalui studi kepustakaan, dokumen pemerintah Kota Kupang, observasi, serta wawancara dengan masyarakat setempat. Berdasarkan hasil analisis terdapat penyimpangan fungsi ruang perkotaan, yang awalnya sebagai ruang publik berubah menjadi kawasan komersil. Dengan demikian, dalam penelitian ini dapat disimpulkan bahwa sebuah ruang dalam perkotaan dapat dinilai dari segi fungsi maupun perannya di dalam kota dan dapat dipengaruhi oleh perkembangan kota dimana terdapat proses adaptasi, negosiasi, serta kekuasaan. Perubahan fungsi pada ruang Kota Kupang dapat menimbulkan berbagai macam masalah perkotaan, diantaranya adalah masalah sosial, lingkungan dan pertumbuhan kota yang tidak seimbang.
\end{abstract}

Kata kunci: habitat, perkotaan, ruang publik, Kota Kupang.

\begin{abstract}
Title: Urban Habitat in Kupang City

The issue of urban space clash in Indonesia is not only in the level of space occupation but also in the loss of habitat-driving force in the city. It is also happening in the city of Kupang as capital of East Nusa Tenggara Province, and also as the border region with the state of Timor Leste. The city of Kupang developing at this time, continues to carry out the growth to the coastal areas. It is in fact contradictory to the regulations that have been made before. The area in this case study of the research is Pasir Panjang Beach - Kelapa Lima, where it is locate in previously a habitat for fishermen colonies in the coastal area of Kupang City. Next to this location is a public space. This study aims to determine the conflict of interest in the space utilization in the city of Kupang. The descriptive research methods will be used, through literature studies, Kupang City government documents, observations, and interviews with local communities. Based on the results of the analysis, there are deviations in the function of urban space, which initially is a public space, then turned into a commercial area. Thus, in this study, it can be concluded that urban space can be assessed in terms of its function and role within the city in reallity can be influenced through the process of adaptation, negotiation, and power play. Changes in function of the urban space can cause various kinds of urban problems, including social issues, the environment, and unbalanced city growth.
\end{abstract}

Keywords: habitat, urban, public space, Kupang City. 


\section{Pendahuluan}

Pertumbuhan dan perkembangan Kota Kupang akhir-akhir ini merupakan konsekuensi dari pesatnya pembangunan di wilayah perbatasan negara Republik Indonesia yang digalakkan oleh pemerintah pusat. Saat ini perlu mendapat perhatian lebih besar agar pada saatnya nanti tidak kembali mengekor kepada kondisi kota-kota yang telah lebih dahulu maju dan terlambat menyadari kondisi yang terjadi di kotanya, kemudian berusaha untuk merubah paradigmanya agar dapat menyiasati laju pertumbuhan dan perkembangan kota. Kota Kupang yang terletak di pesisir pantai merupakan kota perdagangan yang telah tumbuh dan berkembang sejak zaman Belanda. Hal tersebut ditandai dengan adanya pelabuhan sebagai sarana pendaratan waktu itu yang kemudian juga dijadikan sebagai sarana pelayaran dan perdangangan oleh bangsa kolonial. Wilayah sekitar pantai Kupang kemudian berkembang karena pertumbuhan perdangangan warga Tionghoa yang kemudian juga membentuk pecinan sebagai koloni, dengan mata pencaharian berdagang disekitar pesisir pantai Kupang.

Kemudian Kota Kupang berkembang dari waktu ke waktu sebagai perluasan dan pemekaran tata pemerintahan yang membentuk wilayah administrasi baru, sebagai pengembangan kota dan tata pemerintahan sesuai dengan struktur tingkatan pemerintahan yang ada dan terbentuk. Berkembangnya Kota Kupang dengan pola pengembangan kota ini juga semakin lama semakin luas dikarenakan oleh kebutuhan akan permukiman dan lokasi komersial lainnya. Sebagai kota utama di Pulau Timor yang berbatasan langsung dengan negara baru Timor Leste sekaligus sebagai ibukota Provinsi Nusa Tenggara Timur, Kota Kupang kemudian menjadi salah satu fokus pengembangan kawasan perbatasan di Pulau Timor dengan Timor Leste. Saat ini Kota Kupang yang terdiri dari 4 (empat) kecamatan dan 49 (empat puluh sembilan) kelurahan memiliki status sebagai salah satu kota PKN (Pusat Kegiatan Nasional) di Wilayah Timur Indonesia. Selain itu, Kota Kupang juga menjadi salah satu akselerator bagi pembangunan Kawasan Timur Indonesia (KTI), karena keberadaan Pelabuhan Tenau sebagai pelabuhan laut internasional. Dengan demikian, Kota Kupang menjadi pilihan sebagai kawasan permukiman, sumber mata pencaharian, kawasan pendidikan, kawasan perdagangan dan kawasan industri. Kondisi ini memberikan dampak yang luas bagi Kota Kupang, baik dalam tatanan kemasyarakatan, perekonomian dan kondisi lainnya.

Pola permukiman di Kota Kupang pada umumnya terbentuk karena adanya tarikan-tarikan aktivitas yang muncul sebagai pendukung fungsi kawasan perkotaan seperti pemerintahan, perdagangan, perhotelan maupun aktivitas kepariwisataan lainnya. Hal ini terlihat dari kondisi permukiman yang banyak berkembang mengikuti pusat kegiatan kota dan terletak pada struktur jaringan utama kota. Sebaran permukiman yang cukup padat berada di sekitar pusat kota. Mulai padatnya permukimanpermukiman di pusat kota tersebut menyebabkan perkembangan permukiman juga mulai mengambil ruang di sepanjang pantai yang mengikuti jalur utama menuju ke Kabupaten Kupang dan terus-menerus berkembang dari tahun ke tahun tanpa henti.

Lalu bagaimana Kota Kupang bisa relevan bagi warganya, bagaimana kita menciptakan Kota Kupang yang 
nyaman dan layak huni? Peremajaan kota dan bangunan yang ketat, penciptaan ruang publik berkualitas dan sarana prasarana pro-warga yang nyata adalah jawabannya. Seperti apakah kota layak huni? Bagaimana kita melepaskan diri dari cengkeraman kekuatan pemodal yang berselingkuh dengan elite? Kalau saja kita terlambat menyikapi hal ini, tidak mustahil pertumbuhan kota saat ini akan juga berujung pada suatu suasana kota yang tidak layak huni, sebagaimana kotakota terdahulu yang kemudian berada pada situasi stagnan. Ruang luar yang dulunya masih bisa dimanfaatkan secara maksimal dan bebas oleh warga kota, seperti area pesisir pantai dari Oeba sampai Kelapa Lima, yang tadinya masih dengan mudah dapat diakses dan dinikmati oleh masyarakat luas di Kota Kupang perlahan-lahan mulai dikooptasi oleh berbagai kepentingan.

\section{Metode}

Penelitian ini dilakukan melalui studi kepustakaan (library research). Metode analisis yang digunakan adalah metode deskriptif. Analisis deskriptif adalah suatu metode dengan jalan mengumpulkan data, mengklarifikasi dan menginterpretasikannya (Natsir, 1999). Tahapan yang dilakukan dalam penelitian yaitu :

1. Pengumpulan kajian pustaka mengenai kota dan habitat perkotaan.

2. Pengumpulan data dan klarifikasi data dan temuan fakta tentang Kota Kupang dan pesisir pantai Kupang.

3. Membandingkan atau mencocokkan fakta obyek penelitian dengan kajian pustaka.

4. Melakukan penarikan kesimpulan.

Sedangkan data atau dokumen penelitian diperoleh dengan cara:
1. Survey/ pengamatan lapangan.

2. Dokumen dari kepustakaan dan literatur, maupun buku-buku literasi pemerintah Kota Kupang.

3. Wawancara dengan masyarakat setempat dan sekitar obyek pengamatan, diantaranya nelayan pesisir pantai Kelapa Lima Kota Kupang.

\section{Hasil dan Pembahasan}

\section{Dilema Ruang Kota Kampung Nelayan Kelapa Lima dan Penggunaan Ruang Kota Kupang}

Salah satu bagian kota yang sedang berkembang dengan cukup pesat di Kota Kupang saat ini adalah kawasan pesisir pantai Kelapa Lima yang termasuk dalam wilayah Kelurahan Pasir Panjang, Kecamatan Kelapa Lima, Kota Kupang. Hal tersebut memiliki daya tarik untuk dilakukan penelitian terhadap dilema dan proses adaptasi serta negosiasi dalam pemanfaatan ruang kota di wilayah ini, yang dulunya adalah kampung nelayan dengan keseharian mereka setiap hari mencari nafkah dengan menjalani kegiatan melaut di sepanjang pesisir pantai berpasir putih dan sekaligus sebagai tempat rekreasi bagi masyarakat kota lainnya.

Pantai Kelapa Lima selalu menarik perhatian masyarakat Kota Kupang dan sekitarnya. Kota Kupang merupakan kota karang yang terkenal dengan suhu udaranya yang cukup panas dan sangat beruntung memiliki pantai pesisir yang landai dan berpasir putih, sehingga seringkali digunakan masyarakat Kota Kupang sebagai tempat melepas lelah dan rekreasi, karena aksesnya yang sangat mudah dan cukup luas. Selain melepas lelah sekaligus berekreasi masyarakat juga dapat memperoleh kebutuhan akan ikan segar dari para nelayan Pasir Panjang yang melaut dan pulang 
dengan membawa hasil tangkapannya untuk dijual di sepanjang pantai Kelapa Lima. Dengan adanya garis pantai di sepanjang jalur Kelapa Lima yang ditunjang dengan adanya ruas jalan Timor Raya yang menghubungkan Kota Kupang dengan jalur lintas Timor ke Kabupaten Kupang sampai ke Timor Leste, yang bersisian dengan pantai, membuat kawasan ini kemudian tumbuh dan berkembang menjadi settlement kota yang terbentuk secara linear dengan diisi oleh para nelayan pesisir pantai. Dengan berkembangnya Kota Kupang, maka semakin banyak investor yang tertarik untuk menanamkan modalnya di kota ini, terutama untuk menunjang industri pariwisata. Perlahan tapi pasti, kawasan ini mulai dilirik sebagai salah satu kawasan potensial dengan pembangunan industri perhotelan yang semakin hari semakin pesat pertumbuhannya dan berkembang, kontestasi pun mulai terbangun karena koloni nelayan yang tadinya membentuk settlement kota mulai dikooptasi oleh adanya bangunan hotel.

Bermula dari satu hotel, kemudian berkembang dan disusul dengan hotelhotel berikutnya sampai akhirnya mau tidak mau masyarakat kampung nelayan yang tadinya sudah memiliki habitat yang tepat dan sesuai sebagai koloni mereka mulai tergantikan dengan industri yang tidak memiliki keterkaitan langsung dengan aktivitas dan mata pencaharian mereka sebagai nelayan. Ironisnya, penguasa atau pemerintah daerah sendiri tidak menyadari bahwa mendorong industri pariwisata dengan menghadirkan hotelhotel di sepanjang pantai ini berakibat meniadakan ruang atau space bagi kawasan wisata itu sendiri karena pembangunan hotel yang mengokupasi lahan pesisir pantai ini juga diamini oleh pemerintah daerah dengan membangun jogging track di pesisir pantai yang tersisa. Masyarakat yang tadinya adalah nelayan, selain kehilangan kegiatan untuk bisa melaut dengan bebas juga tidak bisa menyesuaikan diri dengan hadirnya industri perhotelan yang memerlukan tenaga kerja dengan kualifikasi tersendiri, sehingga masyarakat nelayan kemudian dengan sendirinya tergeser dan terpinggirkan dari settlement yang terbentuk dari koloni mereka.

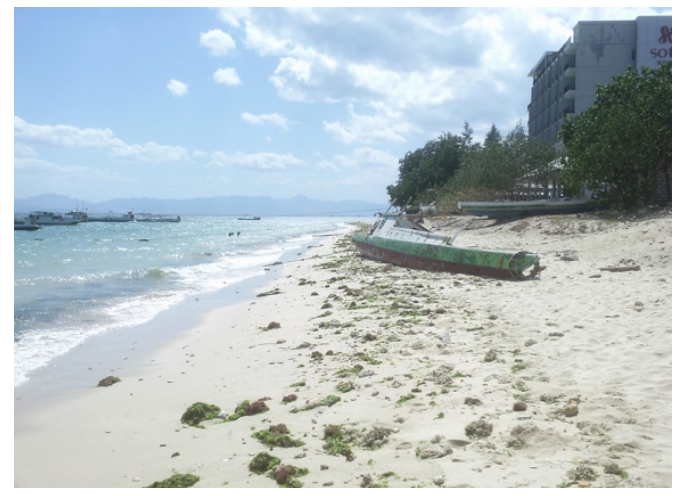

Gambar 1. Pantai Kelapa Lima

Sumber: Dokumentasi pribadi, 2017

Kondisi sepanjang pantai Pasir Panjang yang tumbuh menjadi kawasan perhotelan kemudian menggambarkan "kuasa" atas ruang yang benar-benar tidak bisa dielakkan lagi. Bukan hanya mengganti permukiman nelayan yang tadinya menempati kawasan tersebut dengan bangunan-bangunan hotel dan restaurant, tetapi secara tidak langsung menghilangkan ruang publik bagi masyarakat kota. Ruang publik yang selama ini orang bisa dengan mudah menjangkau kawasan pantai tersebut untuk berekreasi dan menikmati pemandangan pantai yang indah, saat ini hanya disisakan jalan setapak yang tidak memadai sebagai ruang publik maupun akses ke ruang publik. Ruang publik dalam perkembangannya terbagi menjadi dua dimensi, dimensi pertama adalah ruang publik (public 
space), yakni sebuah lokasi yang didesain seminimal apapun, memiliki akses yang besar terhadap lingkungan sekitar, tempat bertemunya manusia/ pengguna ruang publik dan perilaku masyarakat pengguna ruang publik yang satu sama lain mengikuti normanorma yang berlaku setempat (Scurton, 1984). Dimensi yang kedua adalah ruang publik (public sphere) yang menurut Habermass ialah suatu realitas kehidupan sosial dimana terdapat suatu proses pertukaran informasi dan berbagai pandangan berkenaan dengan pokok pokok persoalan yang tengah menjadi perhatian umum sehingga dalam proses tadi terciptalah pendapat umum (McQuail, 2003).

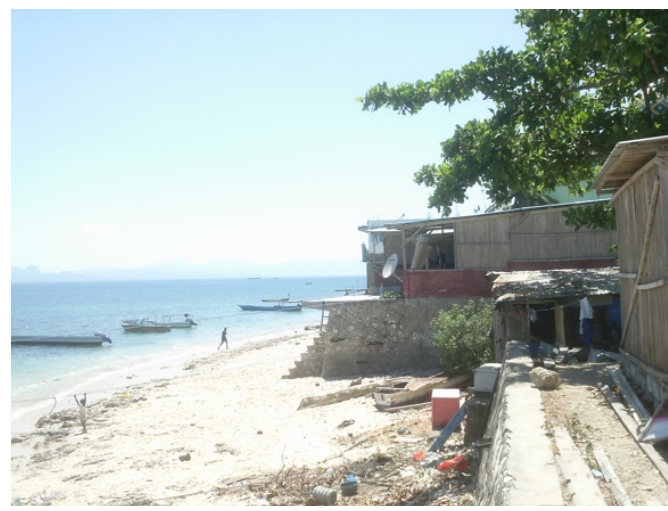

Gambar 2. Rumah nelayan pantai di pesisir Kelapa Lima

Sumber: Dokumentasi pribadi, 2017

Selain perkembangan pembangunan hotel dan restaurant yang terjadi di kawasan pesisir pantai Pasir Panjang dan Kelapa Lima, terlihat juga kondisi permukiman yang banyak berkembang mengikuti pusat kegiatan kota dan terletak pada struktur jaringan utama kota. Sebaran permukiman yang cukup padat berada di Kecamatan Oebobo dan Kecamatan Kelapa Lima, terutama yang berada di sekitar pusat kota. Padatnya permukiman-permukiman di pusat kota yang terus meningkat menyebabkan perkembangan permukiman juga mulai mengambil ruang di sepanjang pantai yang mengikuti jalur jalan utama menuju kabupaten.

Selanjutnya, dengan kondisi dan permasalahan tersebut akan dikaitkan dengan penerapan teori-teori perancangan perkotaan yang sudah ada. Dengan melihat dan mengamati serta membandingkan isu perkotaan yang terjadi, diharapkan dapat memperoleh solusi tentang pemanfaatan ruang-ruang publik di Kota Kupang, seperti kegunaan dan manfaat yang bisa diperoleh warga masyarakat Kota Kupang dan sekitarnya, baik dari keberadaan ruang publik akibat adanya kebijakan pemerintah setempat apakah sudah mengarah kepada pengembangan kota yang layak huni dan berwawasan lingkungan. Atau sebaliknya hanya akan menciptakan hutan beton dibalut jalur hijau yang semakin mengkotakkotakkan warga dalam ruang kaku serta digantikan oleh external internal "quaci" public space berupa fasilitas umum yang biasanya dikelola oleh sector privat dan ada batasan atau aturan yang harus dipatuhi warga, seperti mall, diskotik, restoran dan lain sebagainya. (Carmona, et al., 2003: p. 111). Kenyataan okupasi lahan seperti ini mulai tumbuh dan terus bertambah di Kota Kupang, dimana selayaknya warga kota juga dapat memiliki hak atas ruang dan ruang terbuka atau public space sebagai tempat untuk bersosialisasi dengan sesama warga kota maupun sebagai tempat untuk menjalankan hobinya terutama di kawasan pesisir pantai Pasir Panjang sampai Kelapa Lima.

\section{Konflik Ruang}

Kondisi Kota Kupang yang terus berkembang dari waktu ke waktu selalu diwarnai dengan pola kebijakan pemerintah yang selalu berubah dan berkembang mengikuti kebijakan dari setiap kepala daerah sebagai pejabat 
yang berwenang dan menentukan pengambilan keputusan terkait pengembangan kota dan wilayahnya. Penggunaan ruang kota pun tidak lepas dari campur tangan dan kebijakkan yang dibuat oleh pemimpin daerah, dimana fungsi ruang yang telah ditetapkan dalam peraturan daerah kemudian bisa dibuatkan penyesuaian mengikuti kepentingan dan keinginan penguasa atau pemilik modal dengan tema investasi.

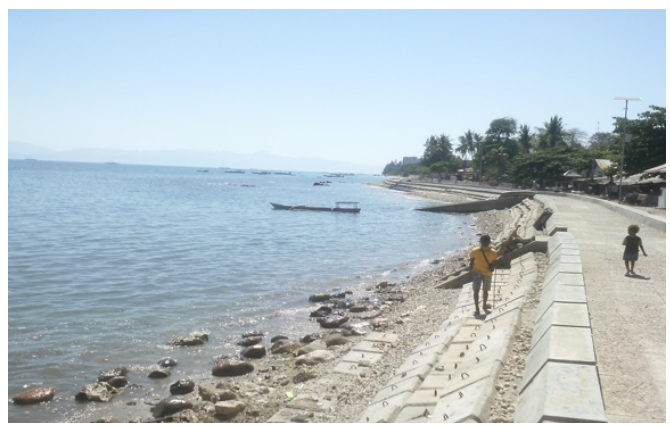

Gambar 3. Pemerintah Kota membangun jalan di pesisir pantai Kelapa Lima Sumber: Dokumentasi pribadi, 2017

Seringkali perubahan peruntukan lahan dapat terjadi sekaligus dengan perubahan peraturan daerah yang telah ditetapkan sebelumnya. Begitu mudahnya penentuan penggunaan lahan hanya melalui pembahasan beberapa pihak saja.

Hal ini juga berdampak langsung pada keharusan penyediaan ruang terbuka yang selama ini masih berorientasi pada pemenuhan akan kebutuhan ruang terbuka publik berupa ruang terbuka hijau publik. Hal ini merupakan salah satu prasyarat di dalam program pembangunan yang dicanangkan oleh pemerintah pusat yaitu $30 \%$ dari luas kota harus dijadikan sebagai Ruang Terbuka Hijau. Akan tetapi, implementasinya masih belum bisa terpenuhi dengan adanya perambahan kawasan pantai menjadi kawasan perhotelan dan komersil oleh pemerintah Kota Kupang.

Akhir-akhir ini warga masyarakat yang menyuarakan kegelisahan mereka akan hilangnya kawasan pantai Pasir Panjang - Kelapa Lima menjadi kawasan perhotelan semakin nyaring terdengar dengan menggugat hilangnya ruang publik sebagaimana yang tertera di dalam peraturan daerah tentang tata ruang Kota Kupang.

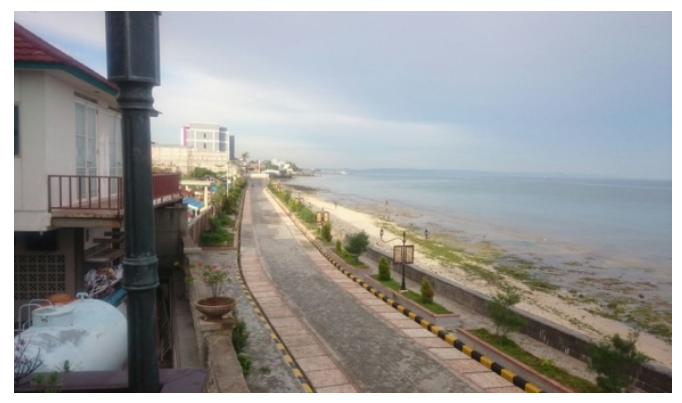

Gambar 4. Jogging track di pesisir Pantai Kelapa Lima

Sumber: Dokumentasi pribadi, 2017

Ruang publik pada dasarnya adalah ruang kosong (open space) yang sangat berguna. Dengan adanya kekosongan, bisa memuat berbagai aktivitas di dalamnya. Selain itu, pada tata ruang kota, adanya open spacel ruang terbuka berguna sebagai ruang pengikat kota sehingga ada jalinan atau penghubung antar ruang di dalam kota. Ruang kosong ini disebut juga arsitektur tanpa atap, dimana ruang ini dengan perumpamaan lantainya dari bumi, dindingnya dari keberadaan bangunan-bangunan dan alam di sekitarnya, serta atapnya berupa langit. Ruang publik ini ada kaitannya dengan open space dan urban space, menurut pendapat Paul D. Spreiregen mengenai open space dan urban space adalah sebagai berikut:

"Open space is another type of space, and one which we should be very careful to understand. Open space generally describes park like areas of greenery in or near the city. It is often 
confused with urban space, which is a formal focus of urban activity. Open space is informal, natural, and parklike. It relieves the harshness of urban form while complementing it. Urban spaces are the products of cities, specifically the juxtaposition of buildings. The larger spaces of nature in which cities sit cannot be enclosed by urban form, but can nonetheless be urban spaces in the sense that they are qualified by the urban presence. The city, as a whole form, accents this vast space." (Spreiregen, 1965).

Sebagian lahan yang telah dimanfaatkan sebagai lahan komersial di kawasan pesisir pantai Pasir Panjang melalui skema sewa pakai lahan sebagai area komersial, yang telah jatuh tempo atau selesai masa kontraknya kemudian mulai digagas untuk dikembalikan sesuai peraturan daerah sebagai ruang publik bagi warga kota. Selama ini ada bagian lahan yang disewa pakai oleh investor, dimana awalnya dengan peruntukan untuk penyediaan ruang publik berupa taman bermain kota, akan tetapi dengan berjalannya waktu kemudian beralih fungsi menjadi area komersial berupa outlet dan area bazar sehingga tidak sesuai lagi dengan peruntukan awal yang sebenarnya. Tidak murni sekali tetapi masih berupa ruang publik yang diprivatisasi oleh pengusaha sehingga tidak bisa dinikmati masyarakat dengan gratis.

\section{Habitat Perkotaan}

Ruang publik biasanya berupa ruang yang dapat dimanfaatkan untuk kegiatan-kegiatan yang sifatnya positif yang biasanya juga dikelola oleh pemerintah. Bentuk dari ruang ini antara lain ruang alami/ semi alami serta buatan, dan lebih dikenal dengan istilah ruang publik dan ruang terbuka publik. Dalam Urban Land Institute, ruang publik yaitu ruang yang berorientasi manusia (people oriented spaces). Sebagai habitat perkotaan, adanya kampung nelayan di pesisir pantai Pasir Panjang dan Kelapa Lima tidak hanya berupa settlement, akan tetapi juga membentuk ruang-ruang publik yang alami dan semi alami yang sangat bagus pemanfaatanya baik secara langsung maupun tidak langsung oleh warga masyarakat kota.

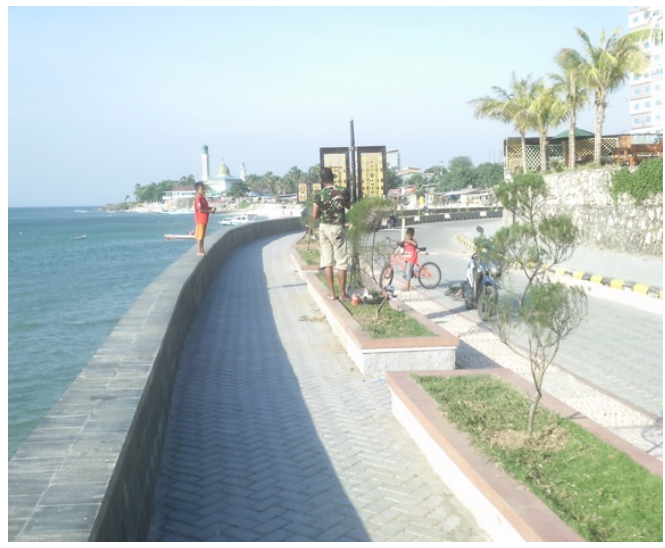

Gambar 5. Pantai Kelapa Lima dibatasi oleh jalan (Jogging track)

Sumber: Dokumentasi pribadi, 2017

Salah satu indikasi suksesnya ruang publik adalah banyak dikunjungi oleh masyarakat. Daya tarik sebuah ruang publik adalah karena sifat manusia merupakan makhluk sosial yang membutuhkan interaksi dengan orang lain. Ruang publik oleh Scurton (1984) dibagi menjadi dimensi publik yakni sebuah lokasi yang didesain seminimal apapun, memiliki akses yang besar terhadap lingkungan sekitar, tempat bertemunya manusia/ pengguna ruang publik dan perilaku masyarakat pengguna ruang publik satu sama lain mengikuti norma-norma yang berlaku setempat.

Ekologi atau lingkungan yang tidak terpisahkan satu sama lain seperti adanya kampung nelayan di pesisir pantai Pasir Panjang - Kelapa Lima dan hamparan pasir yang menghiasi sepanjang pesisir pantai merupakan ruang publik alami. Kemudian 
membentuk suatu habitat perkotaan yang bersentuhan langsung dengan akses transportasi sebagai jalur penghubung. Hal ini memungkinkan perkembangan kota mengikuti jalur akses tersebut tanpa harus mengganggu atau menghilangkan sekaligus habitat dimaksud dengan adanya investasi besar-besaran seperti yang terjadi di Kota Kupang saat ini. Di Kota Kupang ruang-ruang positif atau positive space sebenarnya merupakan ruang alami yang memiliki karakteristik tersendiri, seperti pantai dengan batu karangnya yang unik dan tidak dimiliki oleh daerah lain. Akan tetapi, karena belum dikelola dan dikonsep secara maksimal, sehingga memberi kesan tidak terawat. Jika potensi-potensi tersebut dapat dikelola secara maksimal, maka tidak heran bahwa selain dapat memenuhi kebutuhan masyarakatnya akan ruangruang publik, Kota Kupang juga akan menjadi kota tujuan wisata yang potensial, terutama untuk wisatawisata alamnya yang sangat menarik. Sehingga, dengan sendirinya akan menarik wisatawan atau tourist untuk berkunjung ke Kota Kupang. Banyaknya wisatawan yang datang akan memberi bahkan meningkatkan pemasukan tambahan bagi pendapatan asli daerah tersebut.

Ruang kota secara geometris dibatasi oleh berbagai ketinggian tertentu yang pada akhirnya menjadi bagian yang menyatu dan terpisahkan dari konsep ruang kota tersebut. Pada umumnya, ruang kota merupakan tempat terjadinya kegiatan masyarakat kota sehingga ruang kota menjadi sebuah ruang publik. Dengan tidak melihat dari kriteria estetikanya, Rob Krier (1979) mendefenisikan ruang kota sebagai semua ruang yang berada di antara atau luar bangunan. Di Kota Kupang pemenuhan akan kebutuhan aktivitas warganya terutama di ruang luar berupa ruang terbuka atau ruang publik sudah ada dan sudah mulai dimanfaatkan oleh warga masyarakat Kota Kupang, sebagaimana juga ruang ruang kota di tempat lain termasuk area pesisir pantai. Ada beberapa pembentuk fisik ruang kota menurut Yoshinobu Ashihara (1983), yaitu ruang dalam dan ruang luar. Ruang dalam yaitu ruang yang dibatasi alas, lantai dan dinding. Sedangkan ruang luar adalah ruang yang menjadikan alam sebagai pembatas pada dinding dan alas, dan pada atap dianggap tidak terbatas (langit). Agora di Yunani dan mimbar-mimbar Romawi merupakan ruang publik yang berfungsi sebagai tempat berlangsungnya kegiatan perdagangan maupun kegiatan politik (Catanese, 1979:105; Rubenstein, 1992:2).

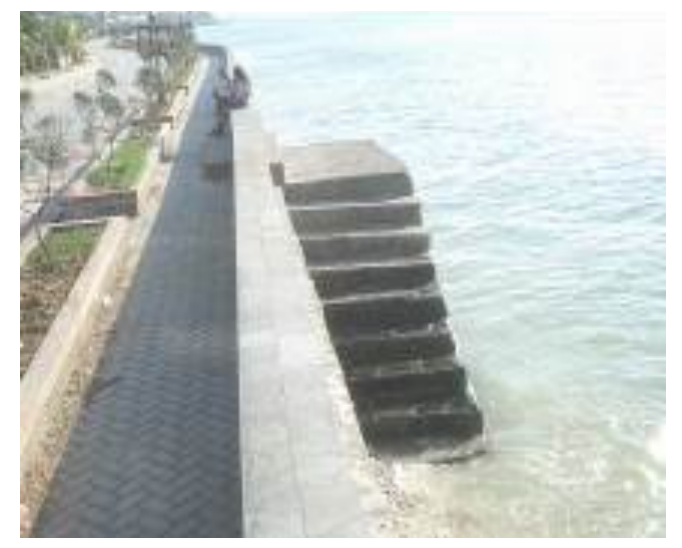

Gambar 6. Ruang publik pantai Kelapa Lima

Sumber: Dokumentasi pribadi, 2017

Ruang publik menurut Habermas ialah suatu realitas kehidupan sosial dimana terdapat suatu proses pertukaran informasi dan berbagai pandangan berkenaan dengan pokok-pokok persoalan yang tengah menjadi perhatian umum sehingga dalam proses tadi terciptalah pendapat umum (public sphere) (McQuail, 2003). Ruang publik pada dasarnya ruang kosong (open space) yang sangat berguna, dengan adanya kekosongan bisa memuat berbagai aktivitas di 
dalamnya, termasuk aktivitas sosial yakni aktivitas yang dilakukan bersama-sama seperti mengobrol, melakukan kontak pasif (melihat atau mendengar) dengan orang lain yang tidak dikenal. Dalam situasi tertentu akan mendorong pengguna untuk kemudian melakukan kontak aktif dengan orang lain tersebut. Aktivitas ini tergantung dari kegiatan yang telah dilakukan sebelumnya atau pengalaman di ruang publik tersebut. Misalnya, anak-anak yang bermain atau mengobrol (Jan Gehl, 1996).

Di Kota Kupang pemanfaatan ruang publik sebagai ruang sosial masih belum membudaya dikarenakan masyarakat lokal tidak terbiasa berkumpul untuk sekedar ngobrol atau bersenda gurau, sehingga ruang sosial ini sering diisi pula dengan kegiatan lain yang lebih aktif, seperti makanmakan atau minum-minum. Kegiatan sosial seperti ini lebih cenderung diakomodir di dalam internal space yang otomatis bersifat privat, seperti di mall dan cafe yang belakangan ini mulai menjamur di Kota Kupang.

Menurut Hakim dan Utomo (2003), salah satu fungsi sosial ruang publik atau open space adalah sebagai tempat berkomunikasi atau bersosialisasi, tempat bermain dan berolah raga, tempat untuk mendapatkan udara segar, tempat menunggu kegiatan lain, pembatas di antara massa bangunan, menghubungkan tempat yang satu dengan yang lain, sarana untuk menciptakan kebersihan, kesehatan, keserasian dan keindahan lingkungan, sebagai sarana penelitian dan pendidikan, serta penyuluhan bagi masyarakat untuk membentuk kesadaran sosial.

\section{Kesimpulan}

Habitat permukiman pesisir pantai Pasir Panjang dan Kelapa Lima di
Kota Kupang yang tadinya masih berupa perkampungan nelayan sebenarnya merupakan koloni yang juga menjadi settlement pembentuk kota. Kemudian, habitat permukiman tersebut telah melewati proses adaptasi dan negosiasi walaupun diselingi dan didominasi oleh kuasa sehingga mengalami perubahan dengan hilangnya habitat dan koloni kawasan tersebut. Saat ini kawasan kampung nelayan di pantai Pasir Panjang Kelapa Lima telah dipenuhi oleh maraknya pembangunan hotel, serta fasilitas penunjang wisata lainnya. Selain fungsi ruang, kepemilikan lahan atau lokasi juga mengalami perubahan menjadi tunggal atau korporasi, kemudian membentuk habitat baru perkotaan. Hal ini dimanfaatkan oleh masyarakat urban, yaitu masyarakat yang tinggal di tempat lain, akan tetapi setiap waktu bisa berada dan beraktivitas di lokasi tersebut karena kebutuhannya.

Selain sebagai habitat permukiman, perkampungan nelayan Kelapa Lima juga membentuk tersedianya ruang publik dalam kota sekaligus memberikan manfaat bagi masyarakat sekitarnya. Manfaat sebuah ruang publik dapat dinilai tercapai atau berhasil bisa dilihat dari berbagai parameter, baik dari segi fungsi maupun perannya di dalam kota. Ruang publik yang telah ada di Kota Kupang tidak boleh hilang hanya karena kepentingan segelintir orang atau penguasa. Sehingga, pada akhirnya ruang publik tidak berhasil dikarenakan selain belum memberikan manfaat dari segi fungsi dan dari sisi konsepnya masih berorientasi kepada pembangunan fisik, serta diprivatisasi bukan pada pembangunan mental dan karakter masyarakat seperti yang dicita-citakan oleh pemimpin negara saat ini, dimana yang ingin dibangun sebetulnya adalah pembangunan 
mental dalam hal ini character building masyarakat.

Indikator yang membentuk terjadinya habitat perkotaan di pesisir pantai Pasir Panjang - Kelapa Lima, yaitu selain adanya jalan penghubung lintas Timor adalah adanya kampung nelayan dengan potensi alam yang menarik. Pada akhirnya berkembang menjadi perebutan kuasa akan lokasi tersebut dengan upaya menghilangkan kampung nelayan dan ruang publik yang tercipta di sekitarnya dengan penyediaan akomodasi dan fasilitas ruang-ruang privat untuk dikomersialkan sebagai buah 'selingkuh' antara pengusaha dan penguasa, dengan melakukan penyesuaian peruntukan bagi lokasi sepanjang pesisir pantai Pasir Panjang - Kelapa Lima.

\section{Daftar Pustaka/ Referensi}

Ashihara, Y. (1983). Exterior design in Architecture. New York: Van Nostrand Reinhold.

Carmona, M., et al. (2003). Public spaces - urban spaces: The dimensions of urban design. Boston, MA: Architectural Press.

Catanese, A. J. dan Snyder, J.C. (1979). Introduction to urban planning. New York: McGrawHill Book Company.

Gehl, J. (1996). Cities for people. Washington DC: Island Press.

Hakim, R. dan Utomo, H. (2003). Komponen perancangan arsitektur landsekap: Prinsipunsur dan aplikasi disain. Jakarta: Bumi Aksara.

Krier, R. (1979). Urban space. New York: Rizzoli.

McQuail, D. (2003). Teori komunikasi massa: Suatu pengantar. Jakarta: PT. Erlangga.

Natsir, M. (1999). Metode penelitian. Jakarta: Ghalia Indonesia.
Rubenstein, H.M. (1992). Pedestrian malls, streetscapes, and urban spaces. USA: John Wiley and Sons Inc.

Scurton, R. (1984). Public space and the classical vernacular. Singapore: The Public Interest.

Spreiregen, P.D. (1965). Urban design: The architecture of towns and cities. New York: McGrawHill Book Company. 